\title{
Correction: Metabolic reprogramming induced by ketone bodies diminishes pancreatic cancer cachexia
}

\author{
Surendra K Shukla1, Teklab Gebregiworgis², Vinee Purohit,3, Nina V Chaika', Venugopal Gunda', \\ Prakash Radhakrishnan ${ }^{1}$, Kamiya Mehla', Iraklis I Pipinos ${ }^{4,5}$, Robert Powers ${ }^{2}$, Fang Yu ${ }^{6}$ and Pankaj K Singh ${ }^{1,3,7,8^{*}}$
}

\section{Correction}

After publication of this Research Article [1], we noticed we had included an incorrect image in Figure 1D in the panel for LiAcAc $20 \mathrm{mM}$. A corrected Figure 1 is included here.

\begin{abstract}
Author details
'The Eppley Institute for Research in Cancer and Allied Diseases, University of Nebraska Medical Center, Omaha, NE 68198, USA. ²Department of Chemistry, University of Nebraska—Lincoln, Lincoln, NE 68588, USA. ${ }^{3}$ Department of Pathology and Microbiology, University of Nebraska Medical Center, Omaha, NE 68198, USA. ${ }^{4}$ Department of Cellular and Integrative Physiology, University of Nebraska Medical Center, Omaha, NE 68198, USA. ${ }^{5}$ Department of Surgery, University of Nebraska Medical Center, Omaha, NE 68198, USA. ${ }^{6}$ Department of Biostatistics, University of Nebraska Medical Center, Omaha, NE 68198, USA. 'Department of Biochemistry and Molecular Biology, University of Nebraska Medical Center, Omaha, NE 68198, USA. ${ }^{8}$ Department of Genetic Cell Biology and Anatomy, University of Nebraska Medical Center, Omaha, NE 68198, USA.
\end{abstract}

Received: 24 September 2014 Accepted: 24 September 2014

Published: 29 September 2014

\section{Reference}

1. Shukla SK, Gebregiworgis T, Purohit V, Chaika NV, Gunda V, Radhakrishnan P, Mehla K, Pipinos II, Powers R, Yu F, Singh PK: Metabolic reprogramming induced by ketone bodies diminishes pancreatic cancer cachexia. Canc Metabol 2014, 2:18.

\section{doi:10.1186/2049-3002-2-22}

Cite this article as: Shukla et al:: Correction: Metabolic reprogramming induced by ketone bodies diminishes pancreatic cancer cachexia.

\footnotetext{
*Correspondence: pankaj.singh@unmc.edu

${ }^{1}$ The Eppley Institute for Research in Cancer and Allied Diseases, University of Nebraska Medical Center, Omaha, NE 68198, USA

${ }^{3}$ Department of Pathology and Microbiology, University of Nebraska Medical Center, Omaha, NE 68198, USA

Full list of author information is available at the end of the article
}

\section{Submit your next manuscript to BioMed Central and take full advantage of:}

- Convenient online submission

- Thorough peer review

- No space constraints or color figure charges

- Immediate publication on acceptance

- Inclusion in PubMed, CAS, Scopus and Google Scholar

- Research which is freely available for redistribution 


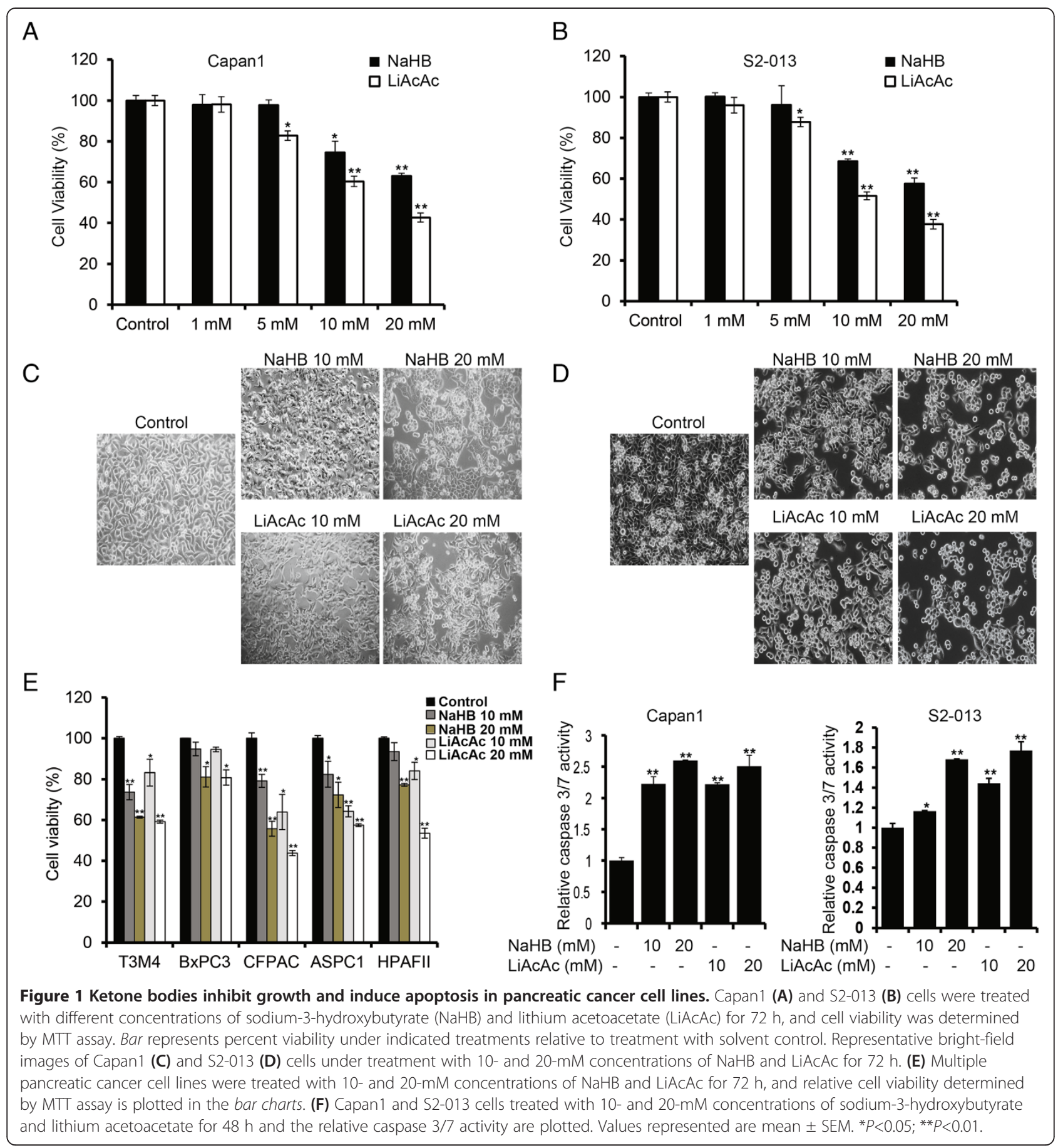

